\title{
Cambrian sedimentary dykes in the Proterozoic basement of the Västervik area (southeast Sweden): episodic formation inferred from macro- and microfabrics
}

\author{
Nadine Friese $\cdot$ Axel Vollbrecht $\cdot$ Bernd Leiss • \\ Olaf Jacke
}

Received: 1 December 2008/Accepted: 12 December 2009/Published online: 27 January 2010

(C) The Author(s) 2010. This article is published with open access at Springerlink.com

\begin{abstract}
Fabrics of Cambrian sedimentary dykes formed in Proterozoic granites of the Västervik area (Southeast Sweden) evidence repeated opening/filling and mineralisation/cementation events under varying conditions. Diagnostic features include (1) wall-parallel boundaries between epiclastic fillings and (2) early formed dyke sediments that appear as lithoclasts in subsequently formed sedimentary fillings. The psammitic components mostly consist of wellrounded quartz grains related to a coastal environment and fragments from the granitic host rock. Platy calcitic fragments embedded in the epiclastic matrix originally formed as microveins within already-lithified dyke sediments and the adjacent host rock. Convex downward-pointing, internal sagging structures, together with the preferred orientation of compositional boundaries and long axes of grains/rock fragments parallel to the dyke walls, are interpreted as the result of suction-controlled flow of unconsolidated fillings during episodes of downward dyke growth. Pressure solution of quartz grains are evidence of extensional phases with dyke propagation that were interrupted by phases of horizontal compression normal to the dyke walls. The $\mathrm{N}-\mathrm{S}$ and NE-SW striking sedimentary dykes formed by opening of a pre-
\end{abstract}

Electronic supplementary material The online version of this article (doi:10.1007/s00531-009-0508-3) contains supplementary material, which is available to authorized users.

N. Friese $(\bowtie) \cdot$ A. Vollbrecht $\cdot$ B. Leiss $\cdot$ O. Jacke

Geoscience Centre, University of Göttingen,

Goldschmidtstrasse 1-3, 37077 Göttingen, Germany

e-mail: nfriese@gwdg.de

A. Vollbrecht

e-mail: avollbr@gwdg.de

B. Leiss

e-mail: bleiss1@gwdg.de existing joint set during NW-SE oriented rifting during the Cambrian.

Keywords Sedimentary dykes - Proterozoic · Southeast Sweden · Microfabrics · Passive infill · Cambrian geodynamics

\section{Introduction}

Sedimentary dykes in crystalline basement rocks have been described from different areas of the Baltic shield (e.g. Bergman 1982; Carlson and Holmquist 1968; Katzung and Obst 1997). They have been interpreted to be of Cambrian age, although only a few fillings could be dated by fossils, which give the maximum age of fissure formation (e.g. Tynni 1982). The age of dyke emplacement is generally accepted to be the age of the feeder bed (Röshoff and Cosgrove 2002). Several mechanisms of the formation of sedimentary dykes have been attributed to the dynamic environment and the physical properties of the host rocks (Röshoff and Cosgrove 2002). Most frequent are neptunain dykes which form by injection of soft sediments caused by pore pressure gradients (e.g. Smart et al. 1988; Winterer et al. 1991; Phillips and Alsop 2000; André et al. 2004; Stanton and Pray 2004; Levi et al. 2006; Heubeck 2009). In contrast, sedimentary dykes in crystalline basement which were formed by downward fracture opening and filled with siliciclastic material supplied from the surface are rarely described (e.g. Beacom et al. 1999).

Geological mapping at the scale of 1:10,000, has been carried out in the Paleoproterozoic of the Västervik area (Southeast Sweden) by diploma students from the Geoscience Centre of the Georg-August-University of Göttingen (Germany). They have discovered several outcrops, where sedimentary dykes cut granitoids (Fig. 1). A compilation of 
further locations concentrated along the coastline, south of Västervik, is given by Alm and Sundblad (2002). With respect to the study area around Västervik, sedimentary dykes have only been described in detail so far from one locality (Carlson and Holmquist 1968), whereas the related microfabrics have only been discussed briefly. According to their strike, the dykes of the Västervik area can be divided into two sets (N-S and NE-SW striking, Fig. 1e), all of which are steeply inclined. Their thicknesses range between 2 and $10 \mathrm{~cm}$, and are rather constant throughout the outcrop
Fig. 1 a Simplified geological map of South Sweden (modified after Beunk and Page 2001) Study area in (b) is marked. b Simplified geological map of the Västervik area (after Lundegårdh et al. 1985; Carlson and Holmquist 1968) with occurrences of sedimentary dykes. Location of the studied sedimentary dyke near Gunnebo is indicated by a star. A Frei (1997), B Weiss (1994),

$C$ Rudolph (1995) and E: Jacke (2000) occurrence each with one sedimentary dyke, $D$ Carlson and Holmquist (1968) describe three dykes. 1 Metasediments of the Västervik formation; 2 TIBGranites; 3 Götemar Granite; 4 Sedimentary dyke. Grid: Gauss projection. c Outcrop photograph showing the studied sedimentary dyke (white dashed line). View towards north, hammer for scale. d Pole plot of joints in granites and corresponding strike direction of main sets (source: 40 diploma mapping projects carried out by students of the University of Göttingen, Germany). e Pole plot of 94 sedimentary dykes occurring in Scandinavia (Västervik area, Tindered area, Götemar/Figeholm, Gotland and Bornholm). A prominent $\mathrm{N}-\mathrm{S}$ striking direction is only observed for sedimentary dykes in the Västervik region, whereas NE-SW and NW-SE striking directions are prominent in all other areas, apart from

Bornholm, there only NW-SE striking trends are documented. Data of sedimentary dykes are from Carlson and Holmquist (1968), Larsson (1975), Weiss (1994), Rudolph (1995), Frei (1997), Katzung and Obst (1997), Jacke (2000), Alm and Sundblad (2002), and Weidemann (2008). The arrows indicate the inferred NW-SE directed Cambrian extension
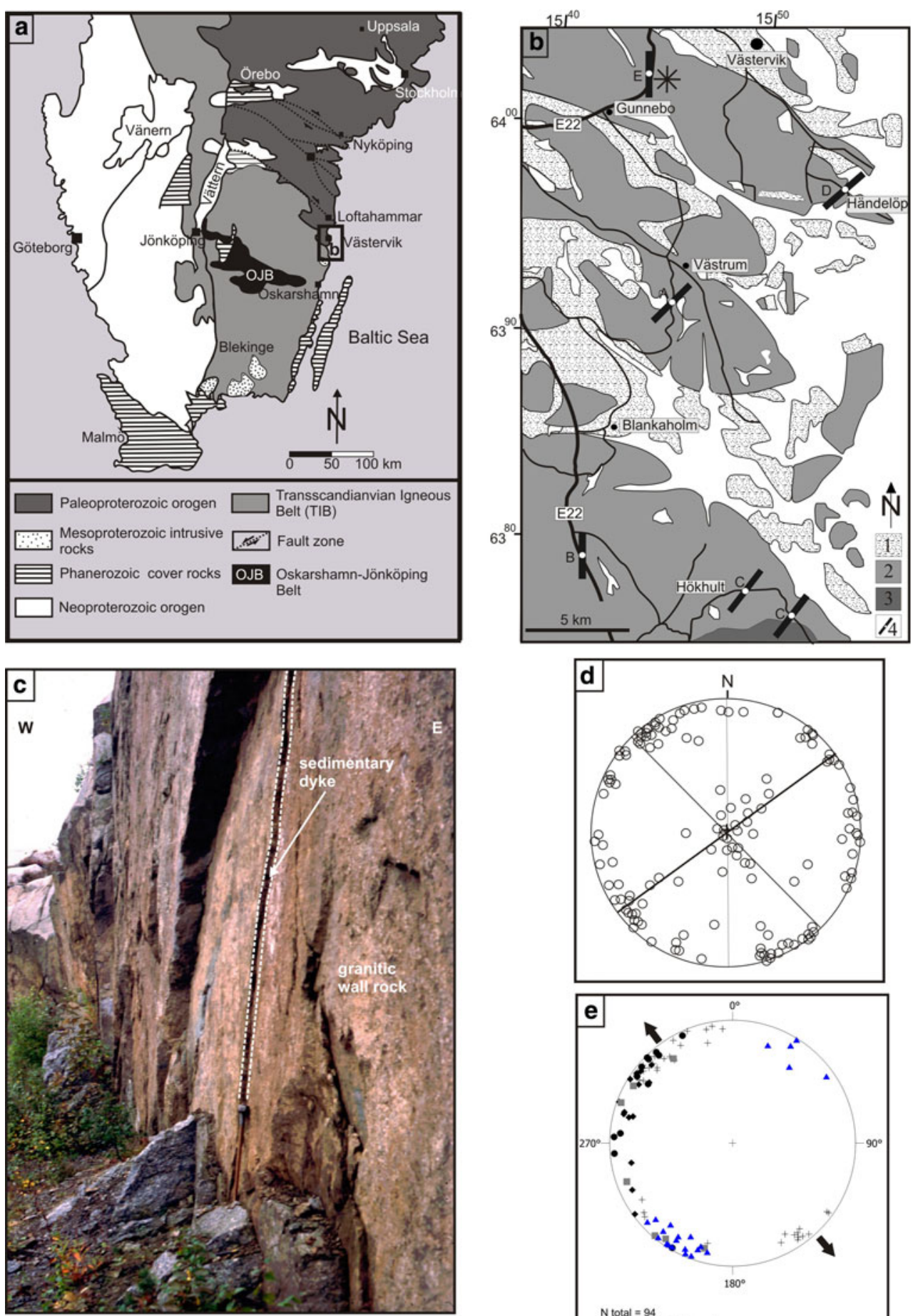

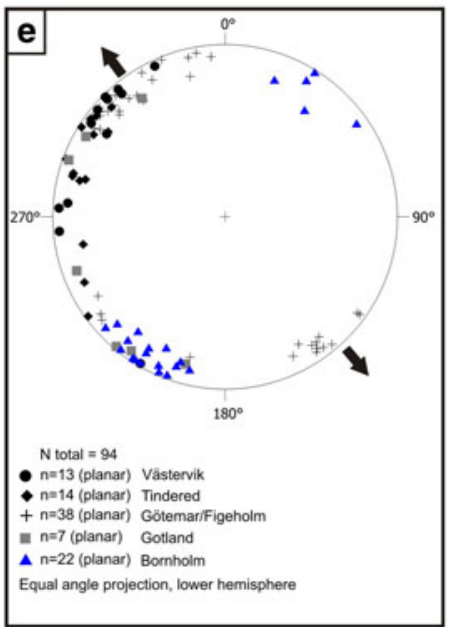


(maximum height of $6 \mathrm{~m}$ ). For the estimation of the original vertical extension of the dykes, post-Cambrian erosion of several tens of metres has to be taken in account (mainly by the Quaternary glacial erosion). Cross-cutting relationships between the two dyke directions have not been observed. Since there are only vertical outcrop sections, possible strikeslip components could not be observed.

Detailed information about the evolutionary history of comparable sedimentary dykes based on comprehensive fabric analysis could not be found in the literature. The present study focuses on the macro- and microfabrics, which show a complex polyphase dyke formation under varying conditions and stress configurations, and hence contributes to the inferred geodynamic situation of SE Sweden in Cambrian times. The samples for this study were collected at a road cut on the E22, approximately $2.5 \mathrm{~km} \mathrm{NE}^{\prime}$ of the village Gunnebo (Fig. 1b, c).

\section{Geological setting}

The study area around Västervik is part of the transition zone between the Svecofennian domain to the north and the Transscandinavian Igneous Belt (TIB) to the south (Fig. 1a). Beunk and Page (2001) proposed a back-arc environment for this crustal segment, which formed in response to Paleoproterozoic, northward-directed subduction beneath the Oskarshamn-Jönköping Belt (OJB; Fig. 1a), approximately $100 \mathrm{~km}$ to the south (Mansfeld et al. 2005).

Remnants of this back-arc basin are represented by the so-called Västervik formation, which mainly consists of metamorphic siliciclastics with intercalated basic flows and sills. The whole sequence was deposited between 1.88 and $1.85 \mathrm{Ga}(\mathrm{U} / \mathrm{Pb}$ ages of detrital zircons) in a continental margin environment (Sultan et al. 2005; Sultan and PlinkBjörklund 2006).

Due to continued subduction, this back-arc basin closed and the Västervik formation was strongly deformed in a dextral transpressional regime associated with metamorphism under high-temperature/low-pressure conditions. Syn- to postkinematic intrusion of various generations of granitoids occurred between 1.85 and $1.65 \mathrm{Ga}$ (Ähäll and Larson 2000; Nolte et al. 2008), which represent the southernmost part of the now-exposed TIB. This basement was deeply eroded by extensive lithospheric uplift and erosion during the late Proterozoic and probably Lower Paleozoic. At that time Baltica was affected by NW-SE extension with respect to the present geographic directions (e.g. Murnier and Talbot 1993; Cocks and Torsvik 2005). On the resultant peneplain, Lower Paleozoic platform sediments of several hundred metres thickness were deposited. This cover was eroded during the Mesozoic and, to a minor amount during the Quaternary by glacial erosion, even below the Cambrian unconformity (Lidmar-Bergström 1997). As a consequence, Cambrian sedimentary dykes, which formed within the $\mathrm{Pa}$ leoproterozoic granitoids, were exposed.

\section{Macrofabrics}

The steeply inclined dykes display rather constant widths throughout the outcrop of between 2 and $10 \mathrm{~cm}$ (Fig. 2). Dyke filling contacts with the granitic wall rock are sharp and planar (Fig. 2a, c, d). The dyke filling consists mainly of layers of sandstone with well-rounded quartz grains alternating with bands of sandy pelites (Fig. 2b). The boundaries between these two main lithological types are diffuse, slightly undulating and mostly sub-parallel to the dyke walls (Fig. 2c, e). Locally, the boundaries are sinusoidal curved with the convex arc pointing downwards (Fig. 2b). In a few cases, fragments of earlier formed and at least partly lithified sedimentary fillings were observed in zones of younger fillings (Fig. 2c). Some sections of the dykes contain larger amounts of angular fragments of the granitic wall rock which are preferentially oriented with their long axis sub-parallel to the dyke boundaries (Fig. 2d). Smaller fragments of the wall rock occur mainly as reddish feldspar grains. A third component is represented by greyish platy calcitic grains which are accumulated in narrow wall-parallel zones in which individual plates are likewise preferentially oriented with their long axes parallel to the dyke walls (Fig. 2e). The platy calcitic grains are up to $2-\mathrm{cm}$ long and $3-\mathrm{mm}$ thick. These aligned plates seem to delineate boundaries between vein fillings of different composition. In the adjacent wall rock, similar carbonate plates of the same size appear as mineralisation in the form of en-echelon arranged (micro) veins (Fig. 2e). Corresponding veins are also observed in lithoclasts of the granitic wall rock (Fig. 2d).

\section{Microfabrics}

Thin sections of the sedimentary dyke were analysed with an optical microscope in plane and crossed polarised light. Carbonate veins were studied in addition with a "hotcathode" cathodoluminescence (CL) microscope (HC3-LM apparatus; Neuser et al. 1995; Pagel et al. 2000) to investigate the in situ formed fabrics of the calcite plates. Thin sections were cut normal to the strike of the dykes. Additional observations for three-dimensional interpretations were made on corresponding hand specimens.

\section{Detrital components}

The psammitic components are predominated by wellrounded monocrystalline quartz grains (Fig. 3a). The 
Fig. 2 Macrofabrics of sedimentary dykes as observed in hand specimens. a Dyke segment with sharp contact to the granitic wall rock. b Three generations of dyke filling; top and bottom dark-coloured filling with high content of pelitic matrix; central segment psammitic filling with calcite cement, convex arc (dashed line) pointing downwards. c Compositional zoning paralle to the dyke wall. Dark finegrained zone contains a fragment of earlier-formed dyke sediment (arrow). d Dyke segment with abundant fragments of the granitic wall rock with long axes aligned subparallel to the dyke boundary. Fragments contain calcite (micro) veins. e Dyke segment with diffuse compositional zoning; zones of platy calcite plates are arranged parallel to the dyke wall, corresponding en-echelon calcite veins in the wall rock
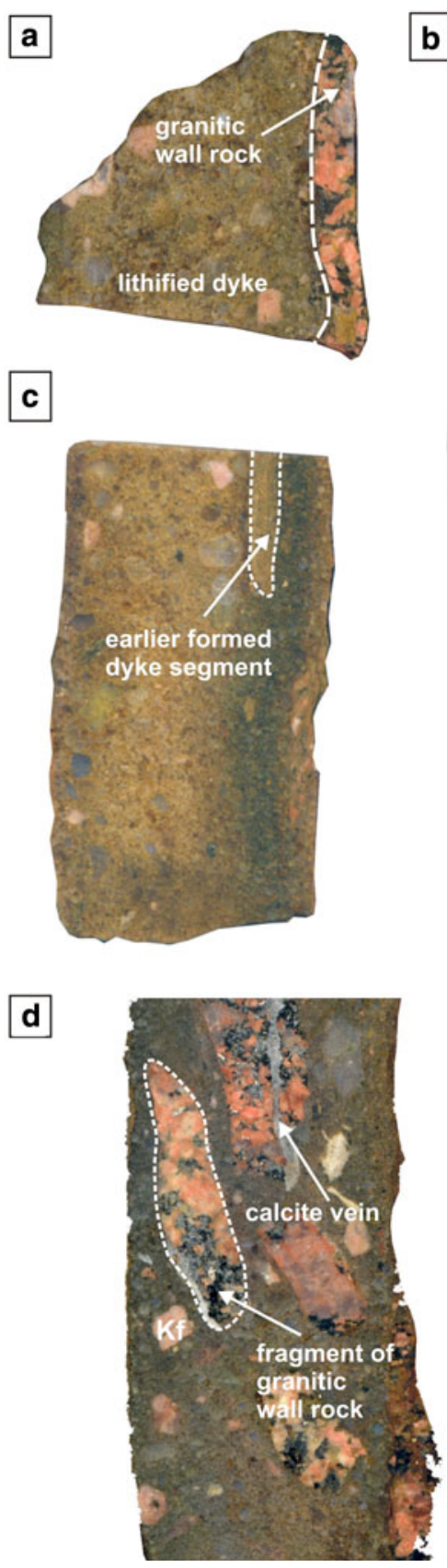

b

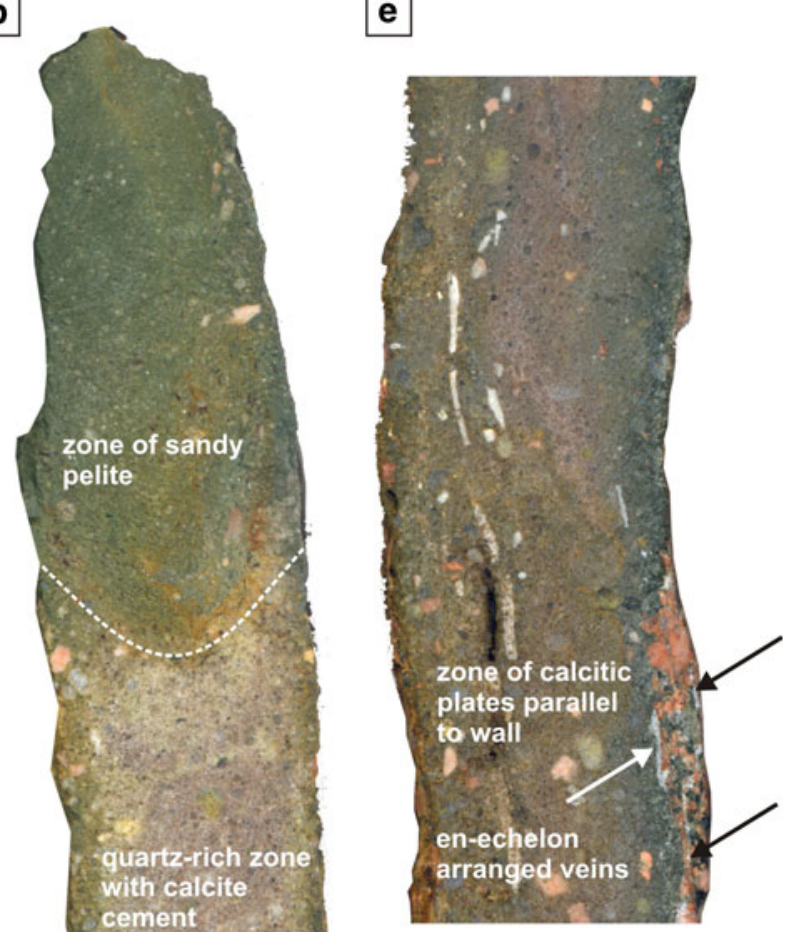

grains are mostly of plutonic type, indicated by dark blue cathodoluminescence colours (Fig. 3b) and lack intragranular deformation structures. A contribution of vein quartz is questionable because grains displaying a diagnostic growth zoning by CL were not observed. A few nonluminescent grains may be derived from low-temperature mineralisation in a diagenetic environment, probably from older Cambrian or Precambrian sandstones deposited in other areas. Other indications of sedimentary source rocks are completely lacking.

Only a very few monocrystalline quartz grains show angular shapes (Fig. 3c), which indicates fracturing shortly before or during deposition into the dyke. Polycrystalline quartz grains (Fig. 3d) are less frequent and display a wide range of crystal sizes and different shapes of internal grain boundaries, which both probably strongly depend on the angle of intersection. These components may have been mostly supplied from the Västervik formation where metaquartzites with a corresponding variety of microfabrics occur (Vollbrecht and Leiss 2008). In rare cases, smaller grains of quartzitic mylonites with distinct textures (lattice-preferred orientations, Fig. 3e) and coherent micro breccias (cataclasites; Fig. 3f) were observed. 
Fig. 3 Spectrum of detrital components. a Well-rounded monocrystalline quartz grains embedded in calcite cement. b Cathodoluminescence image of a comparable fabric domain; blue colours point to plutonic source rocks of the quartz grains. c Example of rarely observed angular quartz grains. d Polycrystalline quartz grain with strongly sutured crystal boundaries. e Quartz mylonite grain showing strong shape- and lattice-preferred orientation (crossed polars and gypsum plate). f Grain of coherent quartzitic breccia. g K-feldspar (Kf) with well-developed microcline twins strongly altered plagioclase (Plag). h Detrital biotite (Biot), slightly deformed by mechanical compaction between quartz grains $(\mathrm{Qz})$ (crossed polars). i Fragment of metaarkosic sandstone (crossed polars). j Fragment of micaschist (crossed polars)
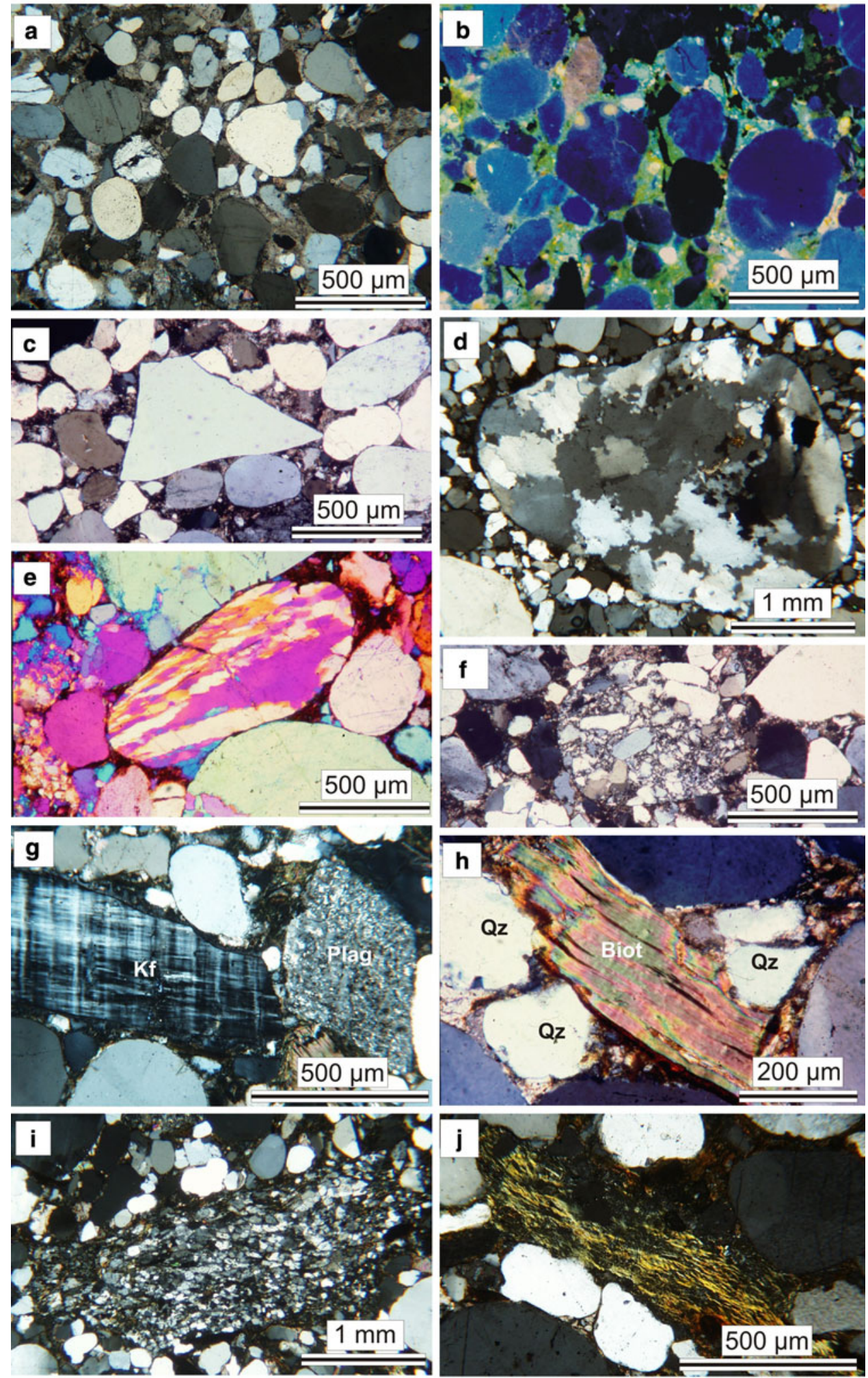

A second group of detrital components is represented by angular or weakly rounded feldspars which are probably derived from granitic rocks in the vicinity or the immediate wall rock. Potassium feldspars are less common, but larger in size, and often display a hypidiomorphic shape with thin perthitic exolution lamellae and diagenetic overgrowth zones. Microcline is abundant with typical cross-twinning, showing only minor alteration, in contrast to plagioclase grains that are often strongly altered to sericite (Fig. 3g). Occasionally, larger flakes of brown biotite were observed 
in quartz/feldspar-rich fabric domains (Fig. 3h), as well as in the pelitic matrix. Zircon, rutile and apatite are the main accessory components.

With the exception of fragments from the granitic wall rock (see above), polymineralic components, for example, metaarkoses (Fig. 3i) or micaschists (Fig. 3j) are comparatively rare. Platy grains of calcite are regarded as fragments of microveins (details see below), which are mixed with the siliciclastic detrital material during later dyke opening and filling steps.

In situ formed fabrics and mineralisations

In the following, basic in situ processes are inferred from microfabrics and mineralisations which are later interpreted in terms of a model of episodic dyke formation.

Mechanical compaction by grain rotation associated with micro-fragmentation was one of the early processes in the unconsolidated sediment. Fragmentation affected quartz grains in primarily porous or clay-rich domains, where rotation of grains or fragments was possible. These domains are best documented by pockets of angular, wellfitting quartz fragments which display a similar crystallographic orientation (Fig. 4a).

In domains of early calcite cementation, mechanical compaction was prevented, indicated by the predominance of point contacts between quartz grains (Fig. 3a). Pressure solution as a second early process is documented by a significant number of quartz grains, which display concavo-convex or sutured boundaries (Fig. 4b, c), particularly in fabric domains poor in pelitic matrix. These boundaries preferentially show subvertical orientations (Fig. 4b) and hence could be related to phases, in which tensional stresses responsible for dyke propagation switched to subhorizontal compressive stresses acting normal to the dyke walls. A corresponding body rotation of elongated grains prior to pressure solution may have contributed to a shape-preferred orientation parallel to the dyke walls, in addition to the previously mentioned dyke-parallel mudsupported flow. Dissolved silica was probably the source for early formed quartz cement which is, due to later replacement by calcite (see below), only preserved as relics (Fig. 4d). Part of the dissolved silica precipitated as cryptocrystalline quartz within the fine-grained pelitic matrix.

In contact with quartz, part of the previously mentioned detrital K-feldspar grains was also affected by pressure solution (Fig. 4e). Precipitation of the dissolved material probably contributed to authigenic overgrowth on potassium feldspars in adjacent strain shadow areas or via mass transfer over longer distance on grains in other fabric domains (Fig. 4f). Corresponding potassium feldspars often display two zones of authigenic overgrowth separated by a dull rim (Fig. 4g). The fact that potassium feldspars with authigenic overgrowth also appear as displaced angular fragments within the matrix (Fig. 4h) is another clear sign of a polyphase dyke formation.

Domains primarily poor in pelitic matrix are filled with sparry to microcrystalline calcite cement, which partly replaced marginal zones of detrital quartz grains and also earlier formed quartz cement (Fig. 5a). In rare cases two generations of sparry calcite cement are clearly discernable (Fig. 5b). Locally, transitions between microcrystalline cement and blocky calcite microveins in quartz were observed (Fig. 5c). The formation of the calcite veins must have affected the already solidified clastic dyke filling because vein propagation occurred not only along grain boundaries but also transgranular, for example by cross-cutting detrital grains of quartz and feldspar (Fig. 5d). Cathodoluminescence colours reveal a distinct growth zonation of individual calcite crystals within sealed microveins (Fig. 5e). This implies a free crystal growth into open fissures associated with an episodic variation in fluid influx during calcite cementation. Moreover, the incorporation of elongated clasts of the wall rock (i.e. of the solidified sedimentary dyke) indicates that the considered calcite veins partly formed by repeated crack-sealing. Another evidence for a comparatively late formation of calcite microveins is that they crosscut the overgrowth rims of potassium feldspars (Fig. 5f).

In patches with higher clay content quartz grains occasionally display a strong pseudomorphic replacement by sparry calcite with conservation of the original rounded grain shape (Fig. 5g). This kind of replacement preferentially affected polycrystalline quartz grains along their boundaries, while monocrystalline grains are mostly preserved.

According to EDX analysis (Jacke 2000, see data in electronic repository), the matrix is mainly composed of microcrystalline aggregates of sericite/illite, chlorite and probably cryptocrystalline quartz, in which larger, in situ formed flakes of chlorite are embedded. Locally, these phyllosillicates display an orthogonal shape fabric symmetrically oriented to the dyke walls (Fig. 6a), particularly in domains with low content of coarse-grained detritus. Larger flakes of chlorite or strongly altered detrital biotite are partly crenulated or marginally delaminated between hard components like quartz or feldspar (Fig. 6b), which indicates mechanical compaction.

Single crystals or aggregates of euhedral to subhedral pyrite represent another in situ formed phase (Fig. 6c). Occasionally, the aggregates are elongated and outline the previously described, steeply inclined boundaries between different generations of detrital fillings. This may indicate that these compositional interfaces served as migration pathways for fluids. 
Fig. 4 In situ formed fabrics I: Mechanical compaction, pressure solution and overgrowth. a Microfragmentation of quartz (crossed polars and gypsum plate). b Subvertical plane or concavo-convex boundaries between quartz grains (crossed polars). c Pressure solution of quartz indicated by sutured grain boundaries (crossed polars). d Relics of quartz cement (arrow; crossed polars and gypsum plate). e K-feldspar (Kf) affected by pressure solution in contact with quartz (arrows; crossed polars). f K-feldspar overgrowth/cement (arrows) and questionable pressure solution of K-feldspar in contact with quartz (crossed polars). g K-feldspar (Kf), displaying two zones of overgrowth, which are partly replaced by calcite $(\mathrm{Cc})$. h Angular grain of K-feldspar with overgrowth on original boundaries, face without overgrowth (arrow) was produced by in situ fragmentation; subsequent separation from counterpart due to flow of pelitic matrix
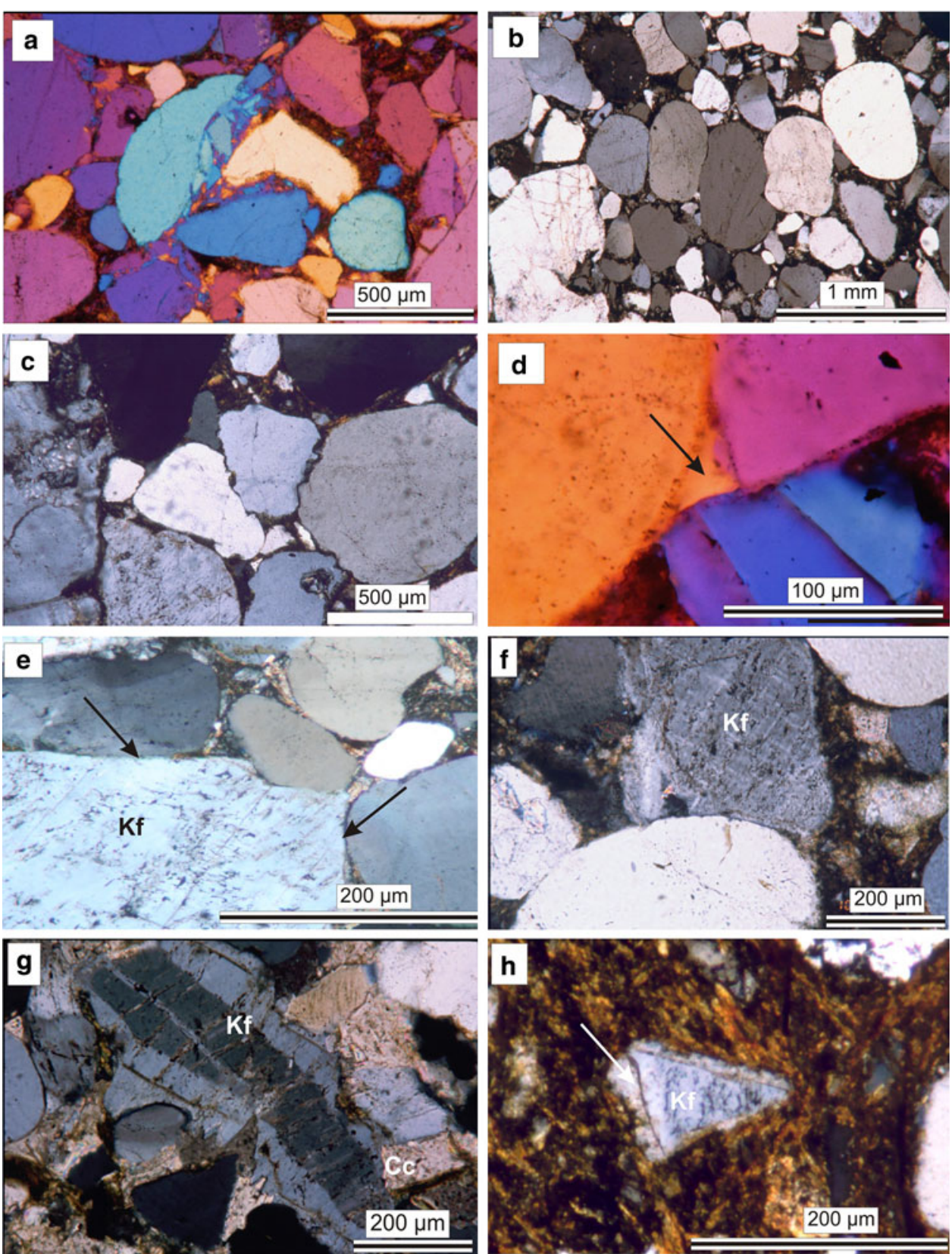

In general, the significant in situ processes comprise soft sediment flow in association with mechanical compaction by grain rotation and micro-fragmentation, pressure solution and re-precipitation, formation of microveins, authigenesis and overgrowth (cementation) partly associated with replacement of pre-existing phases. Primarily variations in composition and porosity, spatiotemporally variations in flow of different pore fluids and local stress heterogeneities caused a heterogeneous distribution of different microfabric domains. Hence, a complete sequence of the dyke-forming processes cannot be reconstructed unequivocally because unambiguous age relationships were established only for restricted fabric domains and hence might not be valid for all the dyke fillings.

\section{Interpretation: tectonic situation and episodic dyke formation}

The investigated dykes can be used as small-scale indicators for the determination of the remote far-field stress pattern (Dunne and Hancock 1994), because a topographic or thermal control on the stress field can be excluded for this tectonic setting. According to their strike directions, 
Fig. 5 In situ formed fabrics II: Calcite mineralisations (all photos taken with crossed polars). a Calcite cement partly replacing monocrystalline quartz grains and quartz cement. b Two generations of sparry calcite cement filling the interstitial between monocrystalline quartz grains. c Microveins of blocky calcite (Cc) transecting

monocrystalline quartz grains (Qz). d Subvertical calcite microvein (dashed white line) with intra- and intergranular sections indicating a solidification of the dyke sediments prior to vein formation. e Cathodoluminescence image of a calcite vein fragment (see Fig. 2e) showing growth zoning of individual crystals. Elongated fragments of a sedimentary dyke (arrows) indicate a calcite vein formation by repeated vein opening and sealing.

f Calcite microvein crosscutting a K-feldspar grain (Kf) with in situ overgrowth zone; fragments of K-feldspar within the calcite vein indicates crack-seal mechanism. g Polycrystalline quartz grain strongly replaced in situ by calcite
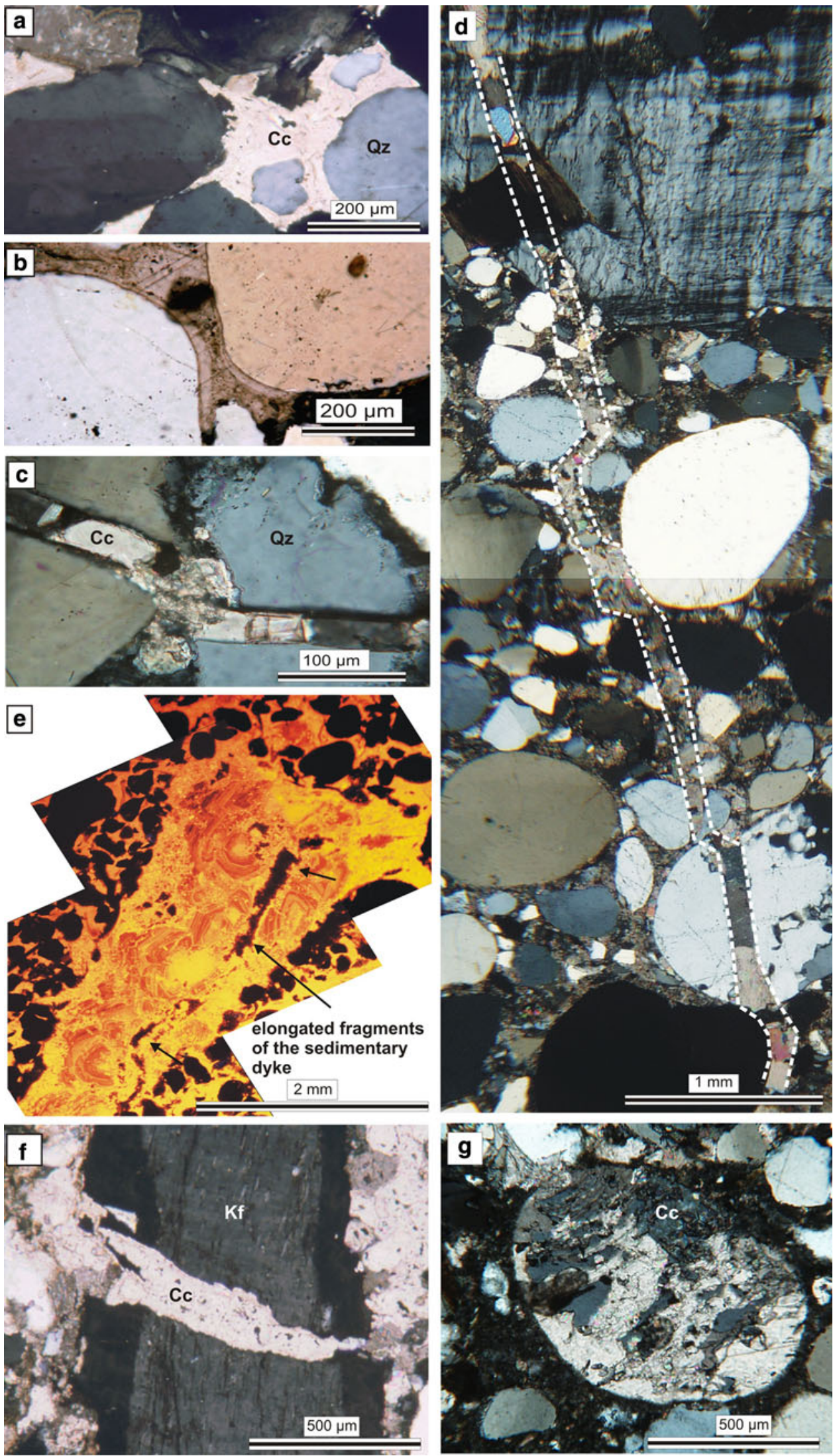
Fig. 6 In situ fabrics III: Matrix. a In situ formed chlorite displaying two conjugate directions of shape-preferred orientations symmetrically inclined to the dyke wall; local crenulation (arrows) point to weak shortening normal to the dyke walls. b Detrital biotite displaying in situ crenulation due to horizontal compression. c Authigenesis of pyrite within the matrix (aggregates of single idiomorphic crystals)
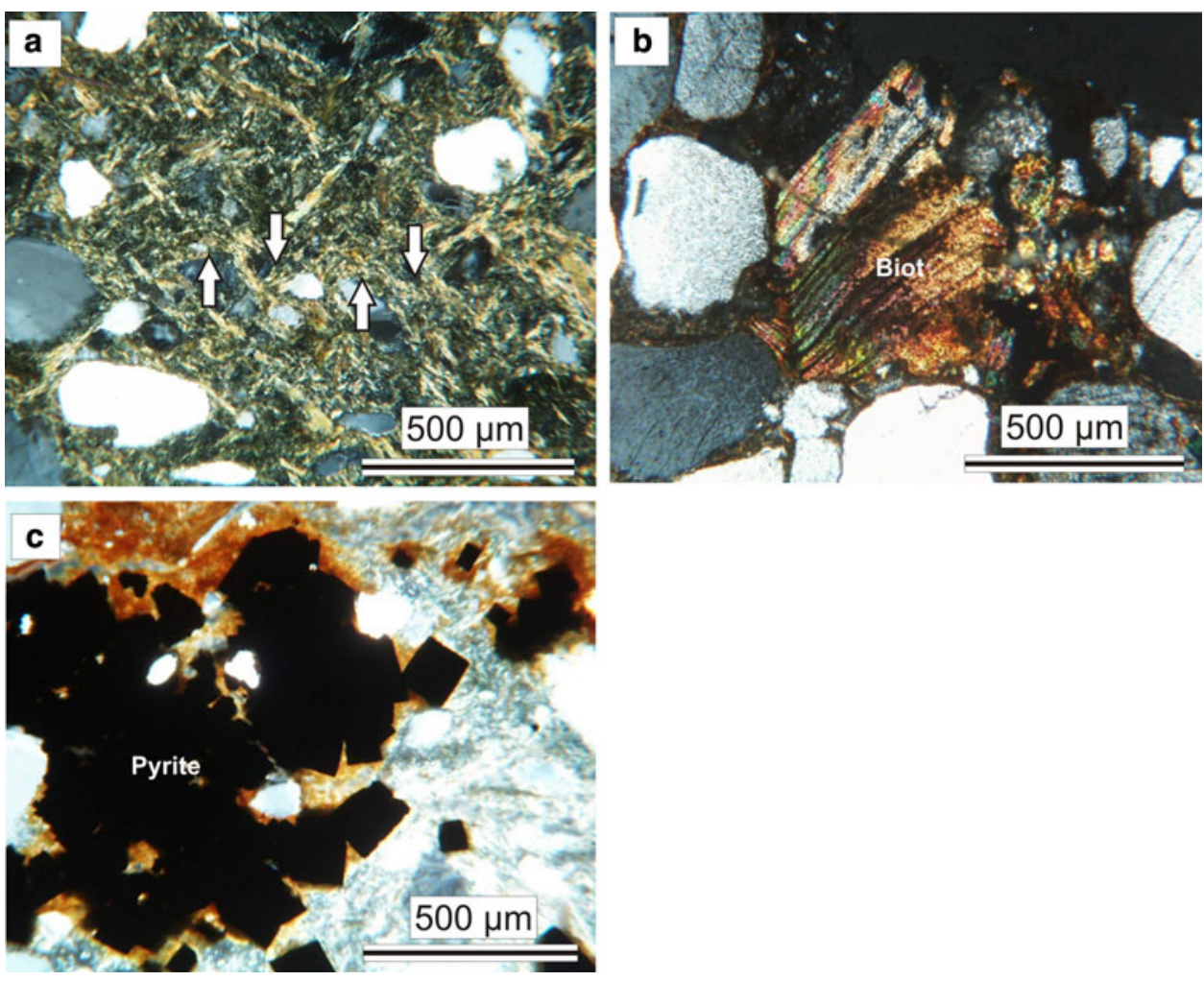

the dyke formation could be related to a NW-SE directed the Västervik formation. One probable explanation for this is that within the metasediments the built-up of critical stress values necessary for dyke formation was prevented due to episodic stress relief by layer-parallel slip. The predominance of moderate to steep inclinations of the metasedimentary strata would be favourable for this process.

As described, K-feldspar displays zones of overgrowth which are later on replaced by calcite. For authigenic feldspar to occur, alkaline pore waters rich in $\mathrm{Na}^{+}$or $\mathrm{K}^{+}$are necessary to convert aluminosilicates in the sediment to feldspar during shallow burial (Kastner and Siever 1979; Tucker 2001). Flehmig (1977) states that both the presence of alkali and silica in seawater are sufficient for feldspar and quartz to form, even during the deposition of sediments. Together with the predominance of well-rounded quartz grains, the formation of the sedimentary dykes can be attributed to a coastal environment which agrees with paleogeographic reconstructions of Hagenfeldt (1989). Clearly, only soft sediments were supplied from the surface, since (exotic) sandstone fragments, which could not be derived from older, already lithified dyke sediments, are lacking.

The following describes a sequence of events which might have occurred repeatedly until individual dykes attained their final dimensions (Fig. 8):

1. Pre-existing joint formed by coalescence of microcracks during the early cooling and uplift history of the
The described sedimentary dykes were only observed in granitic rocks and not in the Proterozoic metasediments of 


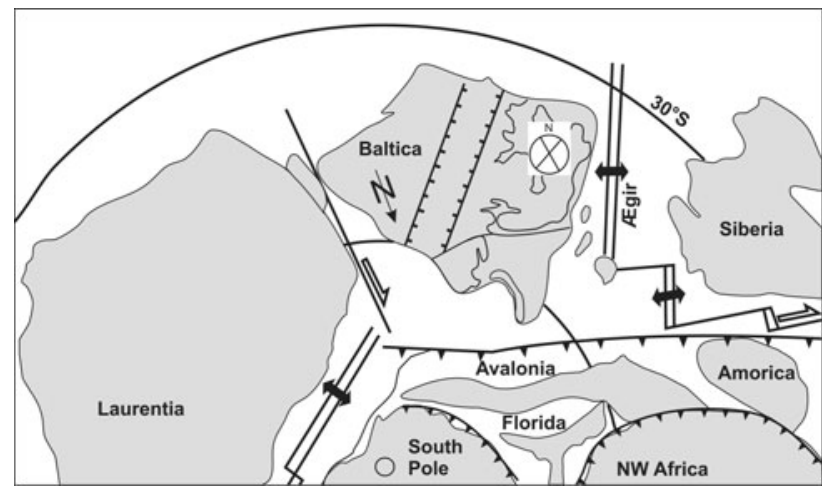

Fig. 7 Schematic illustration of the Cambrian (550 Ma) tectonic framework (modified from Cocks and Torsvik 2005). Equal area polar projection, $N$ gives the present $\mathrm{N}$-direction with respect to Baltica. Rifting of Baltica marked by normal fault symbols. NE-SW and NWSE striking trends of the joints in the Västervik area are indicated as simplified pole plot figure granite in a differential stress field (e.g. Nadan and Engelder 2009 and references therein).

2. Lateral extension of joint and downward propagation of fracture. Simultaneous filling with wall rock fragments, detrital grains and mud from the surface.

3. Further downward fracture propagation caused a suction effect leading to a downward flow of the unconsolidated fillings and reorientation of elongated components and compositional boundaries (sub-) parallel to the subvertical dyke walls. Initial stages are represented by convex-downward boundaries between fillings.

4. Consolidation of fracture fillings due to combined mechanical compaction, pressure solution and precipitation of quartz or authigenesis of potassium feldspar (overgrowth), chlorite and pyrite. Horizontal compression normal to the dyke wall occurred at least temporarily during this consolidation phase.

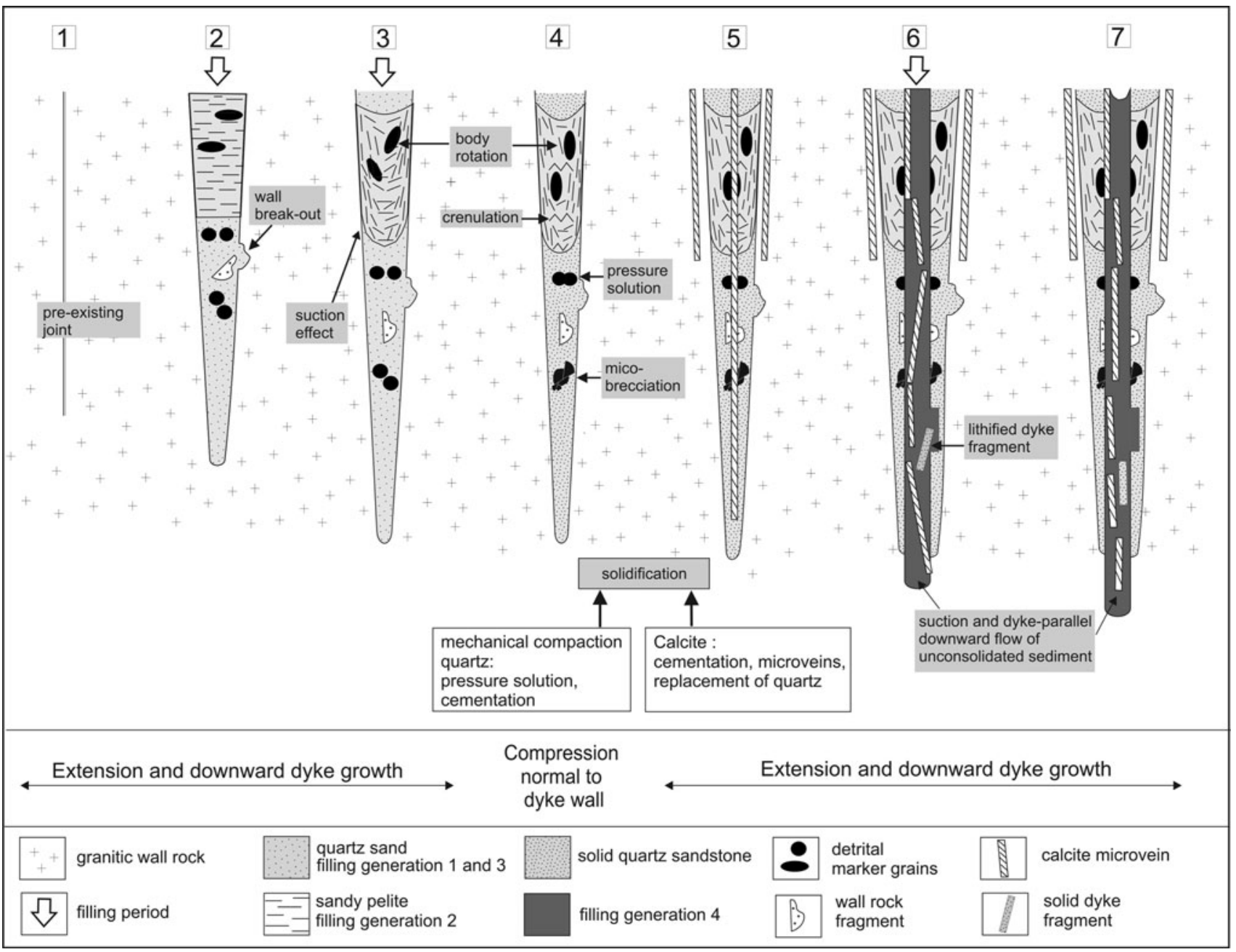

Fig. 8 Model of polyphase dyke development. For explanation of the different stages see text. Structural elements not to scale 
5. Formation of sub-vertical calcite microveins by calcite cementation in fractures through already lithified dyke fillings and the adjacent wall rock. Growth zoning indicates that calcite mineralisation occurred into open fissures. The absence of sediment input may reflect a lack of detritus supply from the surface or that these fissures formed in subsurface levels. Quartz cement and detrital quartz were partly replaced by calcite.

6. Phase of dyke opening transecting already indurated sediments. The newly introduced epiclastic sediments incorporated clasts of the partly fragmented lithified dyke sediments, together with platy fragments of the calcite veins.

7. Progressive downward dyke propagation and related subsidence of the latest sediment fillings, which caused a boudinage-like stretching and strong preferred orientation of the platy calcite fragments parallel to the dyke walls.

\section{Conclusions}

A closer look to the macro- and microfabrics of sedimentary dykes has revealed a multistage origin due to repeated fracture propagation under varying conditions. This may also imply that dyke formation lasted over a long time span with alternating periods of opening/filling, cementation/ lithification and alteration. Taken the results as a whole, a model of passive gravitational infill with unconsolidated sediment from the surface, associated with suction processes due to episodic downward dyke propagation is favoured, rather than injection under high fluid pressure as has been discussed for other sedimentary dykes in Southeast Sweden. Pressure solution of quartz and crenulation of phyllosilicates shows that extensional phases were interrupted by phases of horizontal compression normal to the dyke wall. The orientation of the sedimentary dykes agrees with the regional stress field during the Cambrian. The formation of two sets of dykes was controlled by preexisting sets of joints, which were in suitable orientation to the extensional stress direction. Further analyses of the dyke-forming processes could yield indications for the hosting environment and hence could help to reconstruct the paleogeographic situation and regional tectonics.

Acknowledgments The authors gratefully acknowledge helpful discussions with colleagues from the Geoscience Centre of the GeorgAugust-University of Göttingen. The authors are grateful to Sven Egenhoff and an anonymous reviewer for their constructive comments on the manuscript. We thank David C. Tanner for revising the English.

Open Access This article is distributed under the terms of the Creative Commons Attribution Noncommercial License which permits any noncommercial use, distribution, and reproduction in any medium, provided the original author(s) and source are credited.

\section{References}

Åhäll KI, Larson S ̊ (2000) Growth related 1.85-1.55 Ga magmatism in the Baltic shield; a review addressing to tectonic characteristics of Svecofennian, TIB 1-related, and Gothian events. Geol Fören Stockh Förh 122:193-206

Alm E, Sundblad K (2002) Fluorite-calcite-galena-bearing fractures in the counties of Kalmar and Blekinge. SKB Rapport R-02-42, Swedish Nuclear Fuel and Waste Management Co, Stockholm, Sweden

André G, Hibsch C, Beaudoin B, Carpentier C, Fourcade S, Cathelineau M, Élion P (2004) Oxfordian sedimentary dykes: tectonic and diagenetic implications for the eastern Paris basin. Bull Soc Geol Fr 175:595-605 (in French with English abstract)

Beacom LE, Anderson TB, Holdsworth RE (1999) Using basementhosted clastic dykes as syn-rifting palaeostress indicators: an example from the basal Stoer Group, northwest Scotland. Geol Mag 136:301-310

Bergman L (1982) Clastic dikes in the Åland Islands, SW Finland and their origin. In: Bergman L, Tynni R, Winterhalter B (eds) Palaeozoic sediments in the Rapakivi area of the Aland Islands. Bulletin of the Geological Society of Finland, vol 317, pp 8-32

Beunk FF, Page LM (2001) Structural evolution of the accretional continental margin of the Paleoproterozoic Svecofennian orogen in southern Sweden. Tectonophysics 339:67-92

Carlson L, Holmquist A (1968) Ett nytt fynd av sanstengångar i Västervikstrakten. Geol Fören Stockh Förh 90:519-528

Cocks LRM, Torsvik TH (2005) Baltica from the Late Precambrian to mid-Palaeozoic times: the gain and loss of a terrene's identity. Earth Sci Rev 72:39-66

Dunne WM, Hancock PL (1994) Palaeostress analysis of small-scale brittle structures. In: Hancock PL (ed) Continental deformation. Pergamon Press, Oxford, pp 101-120

Flehmig W (1977) The synthesis of feldspar at temperatures between $0-80^{\circ} \mathrm{C}$, their ordering behaviour and twinning. Contrib Mineral Petrol 65:1-9

Frei M (1997) Mittelproterozoische Magmatite und Metamorphite des Transskandinavischen Magmatit-Gürtels, SW'Västrum, S'Västervik, SE Schweden. Diploma mapping thesis, University of Göttingen, Germany

Hagenfeldt SE (1989) Lower and Middle Cambrian acritarchs from the Baltic Depression and south-central Sweden taxonomy, stratigraphy and palaeographic reconstruction. Ph.D. thesis, University of Stockholm, Stockholm, Sweden, $32 \mathrm{pp}$

Hartz EH, Torsvik TH (2002) Baltica upside down: a new plate tectonic model for Rodinia and the Iapetus Ocean. Geology $30: 255-258$

Heubeck C (2009) Gravel-filled dikes of the Eisenach Formation (Oberrotliegend, Early Permian): modified artesian injections at the base of alluvial fans? Z Dtsch Ges Geowiss 160:41-56 (in German with English abstract)

Jacke O (2000) Petrographie und Gefüge von Sedimentgängen im Granit der Västervik-Region/SE-Schweden. Diploma thesis, University of Göttingen, Göttingen, Germany

Kastner M, Siever R (1979) Low temperature feldspar in sedimentary rocks. Am J Sci 279:435-479

Katzung G, Obst K (1997) The sandstone dyke swarm of Vang, Bornholm (Denmark). Bull Geol Soc Den 44:161-171

Larsson K (1975) Clastic dikes from the Burgsvik Beds of Gotland. Geol Fören Stockh Förh 97:125-134 
Levi T, Weinberger R, AÏfa T, Eyal Y, Marco S (2006) Earthquakeinduced clastic dikes detected by anisotropy of magmatic susceptibility. Geology 34:69-72

Lidmar-Bergström K (1997) A long-term perspective of glacial erosion. Earth Surf Process Landf 22:297-306

Lundegårdh PH, Wikström A, Bruun Å (1985) Provisoriska översiktliga Berggrundskartan Oskarshamn. Sveriges Geologiska Undersökning Ba34

Mansfeld J, Beunk FF, Barling J (2005) 1.83-1.82 Ga formation of a juvenile volcanic arc-implications from $\mathrm{U}-\mathrm{Pb}$ and $\mathrm{Sm}-\mathrm{Nd}$ analyses of the Oskarshamn-Jönköping Belt, southeastern Sweden. Geol Fören Stockh Förh 127:149-157

Marco S, Weinberger R, Agnon A (2002) Radial clastic dykes by salt diapir in the Dead Sea Rift, Israel. Terra Nova 14:288-294

Murnier R, Talbot CJ (1993) Segmentation, fragmentation, and jostling of cratonic basement in and near Äspo, Southeast Sweden. Tectonics 12:713-727

Nadan BJ, Engelder T (2009) Microcracks in New England granitoids: a record of thermoelastic relaxation during exhumation of intracontinental crust. Geol Soc Am Bull 121:80-99

Neuser RD, Bruhn F, Habermann D, Richter DK (1995) Kathodolumineszenz: Methodik und Anwendung. Zbl Geol Paläont I 1(2):287-306

Nolte N, Kleinhans IC, Bäro W, Hansen BT (2008) An evolutionary model of 1,8 Ga granitoids of the Västervik area (SE Sweden) based on a refined geological map. 86th Annual meeting of the German Mineralogical Society, DMG, Berlin, September 14-17 2008, Abstract S07-275

Pagel M, Barbin V, Blanc P, Ohnstetter D (2000) Cathodoluminescence in geosciences. Springer, Berlin

Phillips CA, Alsop GI (2000) Post-tectonic clastic dykes in the Dalradian of Scotland and Ireland: implications for delayed lithification and deformation of sediments. Geol J 35:99-110

Röshoff K, Cosgrove J (2002) Sedimentary dykes in the OskarshamnVästervik area-a study of the mechanisms of formation. SKB Rapport R-02-37, Swedish Nuclear Fuel and Waste Management Co, Stockholm, Sweden

Rudolph S (1995) Mittelproterozoische Magmatite des "Transscandinavian Granite-Porphyry Belt” E'Adriansnäs, Västervikgebiet,
SE Schweden. Diploma mapping thesis, University of Göttinge,Germany

Smart PL, Palmer RJ, Whitaker F, Wright VP (1988) Neptunian dikes and fissure fills: an overview and account of some modern examples. In: James NP, Choquette PW (eds) Paleokarst. Springer, New York, pp 149-163

Stanton RJ, Pray LC (2004) Skeletal-carbonate neptunian dikes of the Capitan Reef: Permian, Guadalupe Mountains, Texas, USA. J Sediment Res 74:805-816

Sultan L, Plink-Björklund P (2006) Depositional environments at a Palaeoproterozoic continental margin, Västervik Basin, SE Sweden. Precambrian Res 145:243-271

Sultan L, Claesson S, Plink-Björklund P (2005) Proterozoic and Archean ages of detrital zircon from the Paleoproterozoic Västervik Basin, SE Sweden: implications for provenance and timing of deposition. Geol Fören Stockh Förh 127:17-24

Tucker ME (2001) Sedimentary petrology, 3rd edn. Blackwell Science, London

Tynni R (1982) On palaeozoic microfossils in clastic dykes in the Aland Islands and in the core samples of Lumparn. In: Bergman L, Tynni R, Winterhalter B (eds) Palaeozoic sediments in the Rapakivi area of the Alland Islands. Bulletin of the Geological Society of Finland, vol 317, pp 35-114

Vollbrecht A, Leiss B (2008) Complex fabric development in Paleoproterozoic metaquartzites of the Västervik Basin, SE Sweden. Geol Fören Stockh Förh 130:41-45

Weidemann M (2008) Structural geology analyses of dykes in the Götemar pluton and its bedrock. Bachelor of Science thesis, University of Göttingen, Germany

Weiss T (1994) Mittelproterozoische Magmatite im "Transscandinavian Fold Belt" S'Blankaholm, SE Schweden. Diploma mapping thesis, University of Göttingen, Germany

Winterer EL, Metzler CV, Sarti M (1991) Neptunain dykes and associated breccias (southern Alps, Italy and Switzerland): role of gravity sliding in open and closed systems. Sedimentology 38:381-404 